\title{
Immature granulocyte count on the new Sysmex XN-9000: performance and diagnosis of sepsis in the intensive care unit
}

BY SABRINA BUORO, TOMMASO MECCA, MAURO VAVASSORI, GIOVANNA AZZARÀ, SARA APASSITI ESPOSITO, PAOLA DOMINONI, GABRIELE PAPAGNI, GIANMARIANO MARCHESI, COSIMO OTTOMANO, ALBERTO CRIPPA, GIUSEPPE LIPPI

\begin{abstract}
Introduction. The amount of immature leukocytes reflects marrow response to bacterial infection, and this may be quantified as the band or immature granulocyte (IG) count. The aim of this study was to analyze the IG count performance of the Sysmex XN-90oo hematology analyzer in intensive care unit (ICU) patients.

Methods. 480 peripheral blood samples from adult patients admitted to the ICU (301 control, 119 sepsis and 6o septic shock) were analyzed with Sysmex XN-90oo. Serum C reactive protein (CRP) was measured on Siemens ADVIA 2400. IG count in peripheral blood was determined either by XN-90oo or optical microscopy (OM). Agreement between the two methods was assessed with Pearson's correlation, Passing-Bablok regression and Bland Altman bias. Diagnostic accuracy was estimated through ROC curves analysis. Sysmex XN-900o imprecision and within-run precision were also evaluated.

Results. Pearson's correlation (r) relative to IG count, as absolute and percentage values, was 0.89 (p < $<.0001$ ) and 0.74 (p <0.0001), respectively, with a Bias of 0.22 and 1.69 respectively. The Area Under the curve (AUC) for the IG count for diagnosing sepsis was greater on XN-900o than OM and equal to the serum CRP. The diagnostic accuracy of IG counts improves when taking into account the conventional criteria for diagnosing sepsis.

Conclusion. IG count appears suitable and reliable when performed using XN-90oo. Even if a modest overestimation was found, the diagnostic accuracy showed by IG analysis on XN-90oo may represent a valid alternative to OM count for diagnosing sepsis in ICU patients.
\end{abstract}

Key words: immature granulocyte, Sysmex XN, sepsis, automated cell count

\section{Introduction}

Sepsis is conventionally defined as a generalized immune response triggered by bacterial, viral, fungal or parasitic infections. (1) Despite remarkable technological advances and improvements in therapeutic management, the high mortality from sepsis in intensive care units (ICUs) has not declined in recent years. As many as 750,00o new cases of severe sepsis are recorded each year in the US, with an overall hospital mortality rate which approximates 30\%. (1) Unfortunately, it has been anticipated that these concerning figures will even worsen in the forthcoming years, due to the ageing of the population, the increased number of immunocompromised patients and resistant microorganisms, the larger use of invasive procedures, as well as the introduction of more accurate diagnostic parameters that will ultimately enhance the number of diagnoses of this condition. $(2,3)$

The accepted criteria for the diagnosis of sepsis, approved by the International Sepsis Definitions Conference, (4) include: documented or suspect infection plus $\geq 1$ of the different variables: general, inflammatory, hemodynamic, organ dysfunction and tissue dysfunction. Notably, the enumeration and differentiation of peripheral blood leukocytes (WBC) (leukocytosis with $\mathrm{WBC}>12.00 \times 10^{9} \mathrm{~L}$, or leukopenia with $\mathrm{WBC}<4.00 \times 10^{9} \mathrm{~L}$ or normal WBC count with $10 \%$ immature WBC), increased values of $\mathrm{C}$ reactive protein (CRP) or procalcitonin (>2SD) are included among the inflammatory variables. The criteria for the diagnosis include sepsis plus organ dysfunction for severe sepsis, and sepsis plus either hypotension (refractory to intravenous fluids) or increased lactate levels for septic shock, respectively. 
According to these criteria, an immature leukocyte count should be regarded as one of the leading diagnostic criteria for the diagnosis of sepsis. $(3,4)$ In the presence of $10 \%$ of more immature forms of WBCs, that are usually reported as immature leukocytes (ILs), the typical picture that emerges is a "left shift" in the leukocyte histogram, which prevalently encompasses a population of "band" neutrophils (NEUT). Unfortunately, the enumeration of band neutrophils by means of Optical Microscopy (OM) in a peripheral blood smear is plagued by limits of applicability and obsolescence compared to the use of automated hematology instrumentation. In fact, the traditional blood smear review requires skilled personnel, is characterized by high imprecision and inter-observer variability, is time consuming and is also plagued by elevated turnaround time (TAT). (5) Unlike OM, the modern generation of hematological analyzers enables fully automated IL count, both in absolute numbers or percentages. (6-10)

The new Sysmex XN-90oo hematological analyzer can operate up to 9 analytical modules in a single system, with various combinations of analyzers and slide preparation units. The fully automated system provides the complete blood cell count (CBC) along with a number of specific hematological parameters, such as Immature Granulocyte (IG) and nucleated red blood cell (NRBC) count with every differential and a throughput that is several times of magnitude higher than that of OM (i.e., each single module cam perform as many as 90 whole blood samples per hour). $(11,12)$

As such, the aim of this study was to evaluate the performance of automatic IG counting on XN-90oo compared with $\mathrm{OM}$, and evaluate the diagnostic performance of these parameters in the diagnosis of sepsis.

\section{Materials and methods}

Subject population

This study was carried out in accordance with the Declaration of Helsinki, and under the terms of all relevant local legislation.

The study included 480 samples obtained from patients admitted to the adult ICU of the General Hospital of Bergamo, Italy (Hospital Papa Giovanni XXIII), between February and March 2014. According to the criteria defined by the International Sepsis Definitions Conference, (4) which takes into account the daily reassessment of the clinical condition of the patients until their discharge from ICU, 301 samples (i.e., 63\%) had no sepsis and were hence defined as controls (CT), 119 (i.e., 25\%) had sepsis (SE) and 60 (12\%) had septic shock (SS). The presence of hematological disorders was excluded in all patients.

Sample preparation and methods

The CBC was performed on $5.4 \mathrm{mg}$ 2.0 $\mathrm{mL} \mathrm{K}_{3}$ EDTA tubes (Becton Dickinson, Franklin Lakes, NJ) whole blood specimens using XN-90oo (Sysmex Co., Kobe, Japan), within 1 hour from collection. The blood smears were also automatically prepared with Autoslider SP-10 (Sysmex Co., Kobe, Japan) and May-Grünwald-Giemsa stained (Carlo Erba Reagents S.p.A. Milano, Italy), and the blood smear review process was performed with DI6o (Sysmex Co., Kobe, Japan). Both Autoslider SP-10 and DI6o were physically connected with the XN-90oo analyzer. The digital images were then reevaluated by a specialist in laboratory hematology, according to the CLSI standard H2O-A2 (13) and the criteria defined by the College of American Pathologists (CAP). $(14,15)$

The parameters evaluated in this study included:

1. The neutrophil count, both absolute (NEUT\#) and percentage (NEUT\%) obtained with XN-90oo, along with the neutrophil count, both absolute (OM-NEUT\#) and percentage (OM- NEUT\%), obtained by OM as previously described;

2. The Immature Granulocyte (IG) count, both absolute (IG\#) and percentage (IG\%) obtained with XN-90oo, along with the IG count (i.e., promyelocytes, myelocytes and metamyelocytes), both absolute (OM-IG\#) and percentage (OM-IG\%), obtained by OM as previously described The within-run imprecision of XN-900o was evaluated using 10 replicates of 5 fresh whole blood routine samples, obtained after routine testing had been completed. The imprecision of Sysmex XN was also assessed according to the CLSI EP5-A2 guideline, (16) by analyzing for 40 consecutive working days, in duplicate, three different levels (1, 2 and 3) of control material (XN-CHECK; Streck Laboratories Inc., Omaha, NE, USA).

The concentration of $\mathrm{C}$ reactive protein (CRP) was also measured on patients' paired serum specimens, using an immunoturbidimetric assay on ADVIA 2400 (Siemens Healthcare Diagnostics USA). The total imprecision of this assay is $<3.4 \%$, as quoted by the manufacturer.

Statistical analysis

The correlation between the counts obtained with XN-90oo and OM was assessed using Pearson's correlation and Passing \& Bablock regression, after verification of normal distribution of values by Kolmogorov-Smirnov test. The 
bias between automatic and manual counting was also assessed with Bland and Altman plots.

The normality distribution of values within the three different classes of subjects (i.e., CT, SE and SS) was then evaluated with Shapiro-Wilk test. The preliminary analysis of data revealed a non-normal distribution of values, so that results were reported as median for each class of subjects. The statistical difference was then evaluated with the nonparametric Kruskal-Wallis and Steel-Dwass-Critchlow-Fligner (pair comparison).

The diagnostic accuracy of the hematological parameters was compared with the criteria defined by the International Sepsis Definitions Conference (4) by means of receiver operating characteristics (ROC) curves, with calculation of sensitivity (SN), specificity (SP) and Correct Classification (CD). The statistical analysis was performed with Analyseit (Analyse-it Software Ltd, Leeds, UK).

\section{Results}

Correlation between $\mathrm{XN}-9000$ and optical microscopy

The Pearson's correlation, Passing \& Bablock regression and Bland Altman bias for IG and NEUT showed better results for XN-90oo than for OM (table 1). The Pearson's correlation (r) for the neutrophil count, between XN-90oo and OM, further increased to 0.99 ( $\mathrm{p}<0.0001$ ) for NEUT \# and 0.84 (p <0.0001) for NEUT\%, respectively, thus confirming the high reliability of the IG count with XN-90oo.

After establishing that values were normally distributed with Kolmogorov-Smirnov CUSUM test, the resulting Passing and Bablok regressions were calculated and showed a better correlation for NEUT\# rather than OM-NEUT\# ( $y=0.99 x-0.19$, table 1). The bias, calculated with Bland and Altman plots, was 0.31 for NEUT\# and -3.08 for NEUT\%, respectively.

The Pearson's correlation (r) of IG count between XN-900o and OM was 0.89 ( $\mathrm{p}<0.0001$ ) for IG\# and 0.74 (p $<0.0001$ ) for IG\%. After establishing that values were not normally distributed with the Kolmogorov-Smirnov CUSUM test, the Passing and Bablok regressions could not be calculated. Nevertheless, the bias calculated with Bland and Altman plots was 0.22 for IG\# and 1.69 for IG\%, which is a sign of overestimation of IG count, both as IG\# and IG\%, even if of modest entity.

Imprecision

The within-run imprecision on XN-9000 was comprised between 2.2\% (mean value $1.58 \times 10^{9} / \mathrm{L}$ ) and 24\% (mean value, $0.10 \times 10^{9} / \mathrm{L}$ ) for IG\#, and between $2.9 \%$ (mean value $21.5 \%$ ) and $25.1 \%$ (mean value $4.2 \%$ ) for IG\%, respectively. It is noteworthy that the sample with the largest imprecision was flagged with the alarm " $A b n$ scattergram", which clearly reflects the unsuitability of XN-90oo for identifying IGs at these threshold values (table 2).

Moreover, the imprecision calculated as CV on the average of 40 consecutive working days for IG\# and IG\% ranged between $3.2 \%$ and $4.3 \%$ (table 3), thus proving that the automated IG count on $\mathrm{XN}-9000$ is robust and precise.

Diagnostic accuracy

The age of the three patient groups was not significantly different, although CT (65 \pm 17 years) were basically younger than both SE ( $66 \pm 12$ years) and SS ( $64 \pm 18$ years). The sex distribution was $27 \%$ females and $73 \%$ males in CT, $27 \%$ females and $73 \%$ males in SE, and 100\% males in SS, respectively. As shown in table 4, the median values of WBC, NEUT\#, NEUT\%, OM-NEUT\#, OM-NEUT\%, IG\#, IG\%, OM-IG\#, OM-IG\% and CRP progressively increased in parallel with the severity of disease that is from CT to SE and SS.

The AUC for diagnosing SE and SS versus CT (figure 1) was always greater for WBC, NEUT\# and NEUT\% than for the other parameters (table 5). Moreover, the Area Under the curve (AUC) of IG\# was also greater than that of OM-IG\# $(\mathrm{p}<0.0001)$ and equal to that of CRP. In particular, although this biomarker exhibited a remarkably high SN (i.e., o.98), its diagnostic usefulness may be strongly impaired by the very modest SP (i.e., o.12)

Interestingly, combined with the conventional diagnostic criteria for sepsis (i.e., leukocytosis with WBC>12.00 $\mathrm{x} 10^{9} / \mathrm{L}$, or leukopenia with WBC $<4.00 \times 10^{9} / \mathrm{L}$, or normal WBC count with $10 \%$ immature WBC) ${ }^{4}$, a $10 \%$ cut-off for IG\% was characterized by a CD of $74 \%$, with $0.72 \mathrm{SN}$ and $0.75 \mathrm{SP}$ for diagnosing sepsis, whereas a $0.150 \mathrm{x} 10^{9} / \mathrm{L}$ cutoff for IG\# was characterized by a CD of $61 \%$, with $0.86 \mathrm{SN}$ and $0.46 \mathrm{SP}$.

With a normal WBC count, another option may be combining the NEUT \# count at $9.38 \times 10^{9} \mathrm{~L}$ cut-off : this set up was characterized by a CD of $72 \%$, with $0.75 \mathrm{SN}$ and 0.46 SP. Instead, with an $80 \%$ NEUT\% cut off we obtained a CD of $80 \%$, with $0.90 \mathrm{SN}$ and $0.42 \mathrm{SP}$. 
An interesting clinical consideration emerges from the analysis of data in table 5, wherein the diagnostic concordance between laboratory criteria and clinical diagnosis was $61 \%$ and $74 \%$ using $10 \%$ or $0.150 \times 10^{9} / \mathrm{L}$ IG cut-offs, respectively.

Therefore, the good correlation with OM, the low imprecision and the excellent diagnostic accuracy support the conclusion that XN-900o may be regarded as a reliable approach for IG counting.

\section{Discussion}

Despite important therapeutic improvement, sepsis remains a major healthcare issue, due to the high mortality worldwide. The prognosis of this condition is strongly influenced by timely diagnosis, so that the introduction of easy, inexpensive and rapid tests should be regarded as an appealing perspective.

Overall, the results of our study show that the new Sysmex XN-90oo displays optimal performance for IG counting, in terms of both imprecision and correlation with OM, which still remains the reference method. Interestingly, the imprecision of IG on the XN-9000 seems even better than that of IG compared with the previous generation Sysmex analyzers and OM. $(6,7,10)$ The analysis of bias shows that the XN-90oo exhibits a trend towards overestimation of both IG\# and IG\% compared to OM, an aspect that was previously described by Maenhout et al. (9) However, unlike data reported by Maenhout, in our study the diagnostic accuracy of IG\# and IG\% on XN-900o was characterized by significantly better AUC ( $\mathrm{p}<0.0001)$ than those exhibited by the same parameters obtained with OM (OM- IG \# and OM-IG\% ) (table 4 and 5).

In a previous paper by Ansari-Lari et al., (8) the observation of increased IG measurements on the Sysmex XE-2100 was shown for infection and sepsis, as well as the biological and clinical relevance of this phenomenon even if IG count lacked sensitivity, as confirmed by our study. Indeed, the diagnostic performance measured in the present study was lower than that reported by Ansari-Lari and others, $(8,17)$ and this is clearly attributable to the fact that we used a more suitable control population (i.e., ICU patients) rather than a group of healthy controls. Unlike in our study, moreover, Ansari-Lari did not use the validated criteria of the International Sepsis Definition Conference (4) for diagnosing sepsis.

Interestingly, the adoption of a 10\% cut-off for IG\% on XN-90oo rather than for IL on OM in patients with a normal WBC count was characterized by satisfactory diagnostic performance for the diagnosis of sepsis (i.e., 0.72 SN and

$0.75 \mathrm{SP}$, respectively). The SE could also be further improved by using a threshold of $0.150 \mathrm{x} 10^{9} / \mathrm{L}$ for IG\# (i.e., 0.86 $\mathrm{SE}$ ), which was however counterbalanced by a much lower SP (i.e., 0.46). According to the AUC, the diagnostic performance of both IG\# was comparable to that of CRP (i.e., AUCs of 0.70 versus 0.72), but the CD of the former parameter was even better (i.e., $61 \%$ versus $44 \%$ ). Interestingly, in the same condition, the use of NEUT\# and NEUT\% parameters showed an AUC and CD of 0.79 versus 0.69 and $72 \%$ versus $80 \%$ respectively.

We can conclude that the assessment of both IG\# and IG\% appears suitable and reliable using XN-90oo. Despite a modest overestimation, the excellent diagnostic accuracy of IGs analysis on XN-90oo may represent a valid and reliable alternative to assessment of IL with OM for diagnosing sepsis in the ICU. This approach also carries some real benefits, such as the lower cost, high throughput, and shorter turnaround time compared to OM. Even more importantly, the opportunity to include novel hematological parameters such as IGs or NEUT in the diagnostic algorithms may help overcome the inherent limits of those currently employed (e.g., ILs), thus helping to develop newer score systems that may ultimately improve the diagnosis of sepsis.

\section{References}

1. Nguyen HB, Rivers EP, Abrahamian FM, Moran GJ, Abraham E, Trzeciak S, et al. Severe sepsis and septic shock: rewiew of the literature and emergency department management guidelines”. Ann Emerg Med 2006;48:28-54.

2. Martin GS, Mannino DM, Eaton S, Moss M. The epidemiology of sepsis in the United States from 1979 through 2000. N Engl J Med 2003;348:1546-54.

3. Angus DC, van Der Poll T. Severe sepsis and septic shock. N Engl J Med 2013;369:840-51.

4. Levy MM, Fink MP, Marshall JC, Abraham E, Angus D, Cook D, et al. International Sepsis Definitions Conference. Crit Care Med 2003;4:1250-6.

5. van der Meer W, van Gelder W, de Keijzer R, Willems H. Does the band cell survive the 21st century? Eur J Haematol 2006:76:251-4.

6. Fernandes B, Hamaguchi Y. Automated enumeration of immature granulocytes. Am J Clin Pathol 2007;128:454-63.

7. Nigro KG, O’Riordan MA, Molloy EJ, Walsh MC, Sandhaus LM. Performance of an automated immature granulocyte count as a predictor of neonatal sepsis. Am J Clin Pathol 2005;123:618-24. 
8. Ansari-Lari MA, Kickler TS, Borowitz MJ. Immature granulocyte measurement using the Sysmex XE-210o relationship to infection and sepsis. Am J Clin Pathol 2003;120:795-9.

9. Maenhout TM, Marcelis L. Immature granulocyte count in peripheral blood by the Sysmex haematology XN Series Compared to microscopic differentiaton. J Clin Pathol 2014; 67:648-50.

10. Bernstein LH, Rucinsky J. Measurement of granulocyte maturation may improve the early diagnosis of the septic state. Clin Chem Lab Med 2011;49:2089-95.

11. Briggs C, Longair I, Kumar P, Singh D, Machin SJ. Performance evaluation of the Sysmex haematology XN modular system. J Clin Pathol 2012;65:1024-30.

12. Tantanate C. Spurious white blood cell count from a new automated Sysmex XN hematology analyzer. Int J Lab Hematol 2014;36(6): 86-7.

13. Koepke JA, van Assendelft OW, Brindza LJ, Davis BH, Fernandes BJ, Gewirtz AS, et al. Reference Leukocyte (WBC) Differential Count (Proportional) and Evaluation of instrumental Methods - Approved Standard, second ed. CLSI document H2OA2, Wayne, PA, 2010.

14. College of American Pathologists. Hematology and Clinical Microscopy Glossary, Illinois, 2012, pp. 3-5.

15. Barnes PW, McFadden L, Machin SJ, Simson E. The international consensus group for hematology review: suggested criteria for action following automated CBC and WBC differential analysis. Lab Hematol 2005;11:83-90.

16. McEnroe RJ, Durham AP, Goldford MD, Kondratovich MV, Lababidi S, Magari R, Middle JG, Pierson-Perry JF, Vaks JE. Evaluation of Precision of Quantitative Measurement Procedures - Approved Guideline, third edition. CLSI guideline EPo5-A3E, Wayne, PA, 2014.

17. Park SH, Park CJ, Lee BR, Nam KS, Kim MJ, Han MY, et al. Sepsis affects most routine and cell population data (CPD) obtained using the Sysmex XN-200o blood cell analyzer: neutrophil-related CPD NE-SFL and NE-WY provide useful information for detecting sepsis. Int J Lab Hematol 2014 May 28. doi: 10.1111/ijlh.12261

Table 1. Pearson's correlation, Passing \& Bablock regression and Bland Altman bias for different cell categories in optical microscopy (OM) versus XN-900o automated count of immature granulocytes (IG) and neutrophils (NEUT). Values in percentage (\%) and absolute number (\#).

\begin{tabular}{|c|c|c|c|c|c|c|}
\hline Test & $\begin{array}{l}\text { Pearson } \\
\text { Correlation }\end{array}$ & $\begin{array}{l}\text { Kolmogorov- } \\
\text { Smirnov CUSUM } \\
\text { test }\end{array}$ & $\begin{array}{l}\text { Passing } \\
\text { \& } \\
\text { Bablock } \\
\text { regressio } \\
\text { n }\end{array}$ & $\begin{array}{l}\text { Slope } \\
(95 \\
\% \\
\text { CI) }\end{array}$ & $\begin{array}{l}\text { Intercept } \\
\text { (95\% } \\
\text { CI) }\end{array}$ & $\begin{array}{l}\text { Bias } \\
\text { Bland } \\
\text { Altman } \\
(95 \% \mathrm{CI})\end{array}$ \\
\hline $\begin{array}{l}\text { OM-NEUT\# } \\
\text { vs NEUT\# }\end{array}$ & $\begin{array}{l}\mathrm{r}=0.99 \\
\mathrm{p}<0.0001\end{array}$ & $\begin{array}{l}\text { Normal } \\
\mathrm{p}=0.4\end{array}$ & $\begin{array}{l}y=0.99 x^{-} \\
0.19\end{array}$ & $\begin{array}{l}0.99 \\
\\
(0.9 \\
8 \text { to } \\
1.00 \\
\text { ) }\end{array}$ & $\begin{array}{l}-0.19 \\
(-0.27 \\
\text { to } \\
-0.095 \\
)\end{array}$ & $\begin{array}{l}-0.31 \\
(-0.37 \text { to } \\
-0.25)\end{array}$ \\
\hline $\begin{array}{l}\text { OM- } \\
\text { NEUT\% vs } \\
\text { NEUT\% }\end{array}$ & $\begin{array}{l}\mathrm{r}=0.84 \\
\mathrm{p}<0.0001\end{array}$ & $\begin{array}{l}\text { Normal } \\
\mathrm{p}=0.5\end{array}$ & $\begin{array}{l}y=1.1 x- \\
11.85\end{array}$ & $\begin{array}{l}1.1 \\
(1.0 \\
\text { to } \\
1.2)\end{array}$ & $\begin{array}{l}-11.85 \\
(-17.00 \\
\text { to } \\
-6.81)\end{array}$ & $\begin{array}{l}-3.08 \\
(-3.52 \text { to } \\
-2.68)\end{array}$ \\
\hline $\begin{array}{l}\text { OM-IG\# vs } \\
\text { IG\# }\end{array}$ & $\begin{array}{l}\mathrm{r}=0.89 \\
\mathrm{p}<0.0001\end{array}$ & Not normal & NA & NA & NA & $\begin{array}{l}0.22 \\
\text { (o.19 to } \\
0.25)\end{array}$ \\
\hline $\begin{array}{l}\text { OM-IG\% vs } \\
\text { IG\% }\end{array}$ & $\begin{array}{l}\mathrm{r}=0.74 \\
\mathrm{p}<0.0001\end{array}$ & Not normal & NA & NA & NA & $\begin{array}{l}1.69 \\
(1.49 \text { to } \\
1.89)\end{array}$ \\
\hline
\end{tabular}

Table 2. The within-run imprecision (expressed as coefficient of variation(CV) and standard deviation (SD)) assessed on five blood samples using XN-90oo for white blood cell (WBC), immature granulocyte (IG) and neutrophils (NEUT) count. Values in percentage (\%) and absolute number (\#).

Mean

Mean

Mean
Mean 


\begin{tabular}{|c|c|c|c|c|c|c|}
\hline & $\begin{array}{l}\text { WBC x10 } / \mathrm{L} \\
\text { (SD e CV\%) }\end{array}$ & $\begin{array}{l}\text { NEUT } \\
\times 10^{9} / \mathrm{L} \\
\text { (SD e } \\
\text { CV\%) }\end{array}$ & $\begin{array}{l}\text { NEUT \% } \\
\text { (SD e } \\
\text { CV\%) }\end{array}$ & $\begin{array}{l}\text { IG X10 } 9 / \mathrm{L} \\
\text { (SD e } \\
\text { CV\%) }\end{array}$ & $\begin{array}{l}\text { IG \% } \\
\text { (SD e } \\
\text { CV\%) }\end{array}$ & $\begin{array}{l}\text { Flags by } \\
\text { XN-90oo }\end{array}$ \\
\hline Sample & $\begin{array}{l}3.61 \\
(S D: 0.053 \\
\text { CV:1.5) }\end{array}$ & $\begin{array}{l}2.14 \\
\text { (SD: } 0.066 \\
\text { CV:3.1) }\end{array}$ & $\begin{array}{l}59.41 \\
(\mathrm{SD}: 1.60 \\
\text { CV1.7) }\end{array}$ & $\begin{array}{l}0.77 \\
\text { (SD 0.017; } \\
\text { CV: 2.2) }\end{array}$ & $\begin{array}{l}21.45 \\
\text { (SD:0.62; } \\
\text { CV: 2.9) }\end{array}$ & $\begin{array}{l}\text { 1. WBC Abnormal } \\
\text { 1. IG Present? } \\
\text { 1. Left Shift? } \\
\text { 1. Fragments? }\end{array}$ \\
\hline $\begin{array}{l}\text { Sample } \\
2\end{array}$ & $\begin{array}{l}13.28 \\
\text { (SD:0.296; } \\
\text { CV:2.2) }\end{array}$ & $\begin{array}{l}9.62 \\
\text { (SD: } \\
\text { o.233; CV: } \\
2.4 \text { ) }\end{array}$ & $\begin{array}{l}72.4 \\
\text { (SD:0.34; } \\
\text { CV: 0.05) }\end{array}$ & $\begin{array}{l}0.59 \\
\text { (SD 0.016; } \\
\text { CV: } 2.6)\end{array}$ & $\begin{array}{l}4.49 \\
(S D: 0.17 \\
\text { CV :3.7) }\end{array}$ & $\begin{array}{l}\text { 1. Atypical } \\
\text { Lympho? } \\
\text { 1. RBC Abnormal }\end{array}$ \\
\hline Sample & $\begin{array}{l}2.41 \\
(S D: 0.065 ; \\
C V: 2.7)\end{array}$ & $\begin{array}{l}1.29 \\
\text { (SD:0.043; } \\
\text { CV 3.4) }\end{array}$ & $\begin{array}{l}53.43 \\
\text { (SD:1.37; } \\
\text { CV: } 2.6 \text { ) }\end{array}$ & $\begin{array}{l}0.100 \\
(S D 0.024 ; \\
C V: 24.0)\end{array}$ & $\begin{array}{l}4.16 \\
(S D: 1.04 ; \\
C V: 25.1)\end{array}$ & $\begin{array}{l}\text { 1. Left Shift? } \\
\text { 1. Abn Lympho? } \\
\text { 1. PLT Abn } \\
\text { Distribution } \\
\text { 1. Abn Scattergram } \\
\text { 1. RBC Abnormal }\end{array}$ \\
\hline $\begin{array}{l}\text { Sample } \\
4\end{array}$ & $\begin{array}{l}13.63 \\
\text { (SD:0.208; } \\
\text { CV:1.5) }\end{array}$ & $\begin{array}{l}11.59 \\
\text { (SD:0.193; } \\
\text { CV: 1.7) }\end{array}$ & $\begin{array}{l}85.10 \\
\text { (SD:0.48; } \\
\text { CV: 0.6) }\end{array}$ & $\begin{array}{l}0.890 \\
\text { (SD: } 0.042 ; \\
\text { CV:4.7) }\end{array}$ & $\begin{array}{l}6.51 \\
\text { (SD: 0.29; } \\
\text { CV:4.5) }\end{array}$ & $\begin{array}{l}\text { 1. IG Present } \\
\text { 1. RBC Abnormal } \\
\text { 1. Leucopenia } \\
\text { 1. Anemia }\end{array}$ \\
\hline $\begin{array}{l}\text { Sample } \\
5\end{array}$ & $\begin{array}{l}\text { (SD: } 0.083 ; \mathrm{CV} \\
: 1.0)\end{array}$ & $\begin{array}{l}\text { (SD: } \\
\text { 0.093; CV: } \\
\text { 1.3) }\end{array}$ & $\begin{array}{l}85.94 \\
\text { (SD:0.47; } \\
\text { CV: 0.5) }\end{array}$ & $\begin{array}{l}1.576 \\
\text { (SD: } 0.063 \text {; } \\
\text { CV: } 4.0 \text { ) }\end{array}$ & $\begin{array}{l}\text { (SD: } \\
\text { o.8o; } \\
\text { CV:4.3) }\end{array}$ & $\begin{array}{l}\text { 1. Left Shift? } \\
\text { 1. Abn Lympho? } \\
\text { 1. PLT Abnormal }\end{array}$ \\
\hline
\end{tabular}

RBC, red blood cells; PLT, platelets.

Table 3. The imprecision (expressed as a coefficient of variation (CV) and standard deviation (SD) assessed on three control levels XN-CHECK using XN-90oo for white blood cell (WBC), immature granulocyte (IG) and neutrophil(NEUT) count. Values in percentage (\%) and absolute number (\#).

\begin{tabular}{|c|c|c|c|c|c|}
\hline & $\begin{array}{l}\text { Mean } \\
\text { WBC } \times 10^{9} / \mathrm{L} \\
\text { (SD e CV\%) }\end{array}$ & $\begin{array}{l}\text { Mean NEUT\# } \\
\times 10^{9} / \mathrm{L} \\
\text { (SD e CV\%) }\end{array}$ & $\begin{array}{l}\text { Mean } \\
\text { NEUT\% } \\
\text { (SD e CV\%) }\end{array}$ & $\begin{array}{l}\text { Mean } \\
\text { IG\# X10 } \% / \mathrm{L} \\
\text { (SD e CV\%) }\end{array}$ & $\begin{array}{l}\text { Mean IG \% } \\
\text { (SD e CV\%) }\end{array}$ \\
\hline $\begin{array}{l}\text { XN-CHECK } \\
\text { Level } 1\end{array}$ & $\begin{array}{l}2.91 \\
\text { (SD: 0.07; } \\
\text { CV:2.5) }\end{array}$ & $\begin{array}{l}1.14 \\
\text { (SD: 0.04; } \\
\text { CV:3.6) }\end{array}$ & $\begin{array}{l}38.8 \\
\text { (SD: o.o3; } \\
\text { CV:3.5) }\end{array}$ & $\begin{array}{l}0.29 \\
\text { (SD: 0.03; } \\
\text { CV:4.3) }\end{array}$ & $\begin{array}{l}10 \\
\text { (SD: } 0.37 \\
C V: 3.7)\end{array}$ \\
\hline $\begin{array}{l}\text { XN-CHECK } \\
\text { Level } 2\end{array}$ & $\begin{array}{l}6.74 \\
\text { (SD:0.104; } \\
\text { CV:2.1) }\end{array}$ & $\begin{array}{l}2.89 \\
\text { (SD: o.09; } \\
\text { CV:2.8) }\end{array}$ & $\begin{array}{l}43.4 \\
\text { (SD: 0.02; } \\
\text { CV:4.9) }\end{array}$ & $\begin{array}{l}0.73 \\
\text { (SD: 0.03; } \\
\text { CV:3.5) }\end{array}$ & $\begin{array}{l}11 \\
\text { (SD: } 0.35 \\
C V: 3.2)\end{array}$ \\
\hline $\begin{array}{l}\text { XN-CHECK } \\
\text { Level } 3\end{array}$ & $\begin{array}{l}15.91 \\
\text { (SD:0.25; } \\
\text { CV:1.6) }\end{array}$ & $\begin{array}{l}7.59 \\
\text { (SD: 0.19; } \\
\text { CV:2.5) }\end{array}$ & $\begin{array}{l}47.8 \\
\text { (SD: 1.08; } \\
\text { CV:2.3) }\end{array}$ & $\begin{array}{l}1.92 \\
\text { (SD: 0.07; } \\
\text { CV:3.7) }\end{array}$ & $\begin{array}{l}12.1 \\
(\mathrm{SD}: 0.41 \\
\mathrm{CV}: 3.4)\end{array}$ \\
\hline
\end{tabular}


Table 4. Diagnostic accuracy of three different cell categories: leucocyte (WBC), neutrophils (NEUT) and immature granulocyte (IG) count using XN-90oo, of two cell category: neutrophils (OM-NEUT) and immature granulocyte (OM-IG) in optical microscopy (OM) and concentration of $\mathrm{C}$ reactive protein (CRP).

\begin{tabular}{|c|c|c|c|c|c|c|c|}
\hline \multirow{3}{*}{ Parameters } & \multirow{3}{*}{$\begin{array}{l}\text { Median } \\
\text { Controls } \\
\text { (CT) } \\
\text { (95\% } \\
\text { CI) }\end{array}$} & \multirow{2}{*}{$\begin{array}{l}\text { Median } \\
\text { Sepsis } \\
\text { (SE) }\end{array}$} & \multirow{2}{*}{$\begin{array}{l}\text { Median } \\
\text { Septic } \\
\text { Shock } \\
\text { (SS) }\end{array}$} & $\begin{array}{l}\text { Kruskal- } \\
\text { Wallis } \\
\text { test }\end{array}$ & & \multirow{3}{*}{$\begin{array}{l}\text { Cut- } \\
\text { off }\end{array}$} & \multirow{3}{*}{$\begin{array}{l}\text { Sensitivity Specificity } \\
\text { (SN) } \quad \text { (SP) }\end{array}$} \\
\hline & & & & $\begin{array}{l}\text { test } \\
\mathrm{X}^{2}\end{array}$ & (95\% CI) & & \\
\hline & & $\begin{array}{l}(95 \% \\
\text { CI) }\end{array}$ & $\begin{array}{l}\text { (95\% } \\
\text { CI) }\end{array}$ & $\begin{array}{l}\text { approxim } \\
\text { ation and }\end{array}$ & $\begin{array}{l}\text { and } p- \\
\text { value }\end{array}$ & & \\
\hline
\end{tabular}

\begin{tabular}{|c|c|c|c|c|c|c|c|c|c|}
\hline & $9.13 \& \S$ & 13.88 & 13.74 & 116.93 & & $\begin{array}{l}>12 \\
\times 10^{9} / \mathrm{L}\end{array}$ & & & \\
\hline $\begin{array}{l}\text { WBC } \\
\times 10^{9} / \mathrm{L}\end{array}$ & $\begin{array}{l}\left(8.83^{-}\right. \\
9.78)\end{array}$ & $\begin{array}{l}(13.11- \\
14.57)\end{array}$ & $\begin{array}{l}\left(9.43^{-}\right. \\
17.50)\end{array}$ & $<0.0001$ & $\begin{array}{l}\left(0.74^{-}\right. \\
0.83) \\
\mathrm{p}<0.0001\end{array}$ & $\begin{array}{l}<4 \\
\times 10^{9} / \mathrm{L}\end{array}$ & 0.71 & 0.77 & $75^{\circ}$ \\
\hline
\end{tabular}

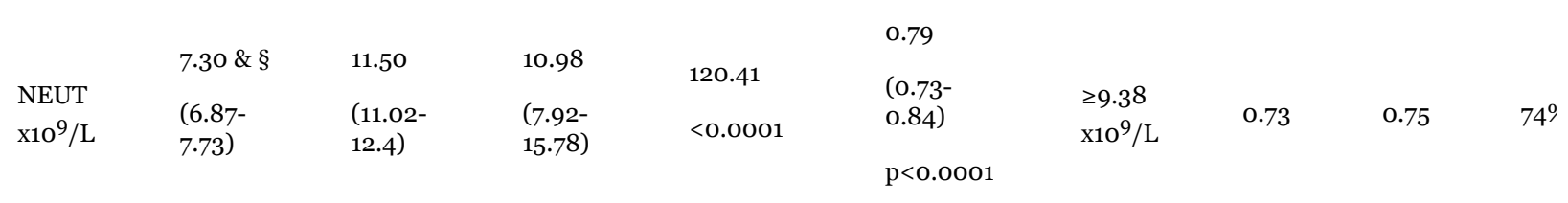

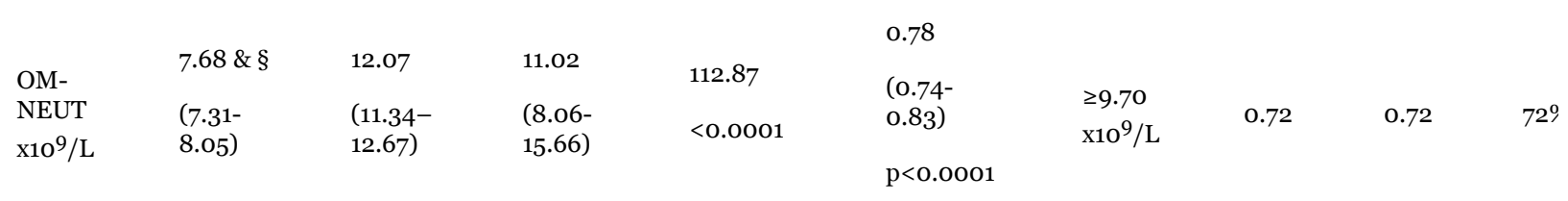

\begin{tabular}{|c|c|c|c|c|c|c|c|c|c|}
\hline \multirow{4}{*}{ NEUT\% } & \multirow{3}{*}{$\begin{array}{l}80.1 \& \S \\
\text { (o.78.9- } \\
81.0)\end{array}$} & \multirow{3}{*}{$\begin{array}{l}84.7 £ \\
\left(81.5^{-}\right. \\
86.5)\end{array}$} & \multirow{3}{*}{$\begin{array}{l}87.6 \\
\left(83.5^{-}\right. \\
92.9)\end{array}$} & \multirow{3}{*}{$\begin{array}{l}51.11 \\
<0.0001\end{array}$} & \multirow{3}{*}{$\begin{array}{l}0.69 \\
(0.64- \\
0.74)\end{array}$} & \multirow[b]{3}{*}{$\geq 80 \%$} & \multirow[b]{3}{*}{0.73} & \multirow[b]{3}{*}{0.49} & \\
\hline & & & & & & & & & \\
\hline & & & & & & & & & $58^{\circ}$ \\
\hline & & & & & $\mathrm{p}<0.00$ & & & & \\
\hline
\end{tabular}

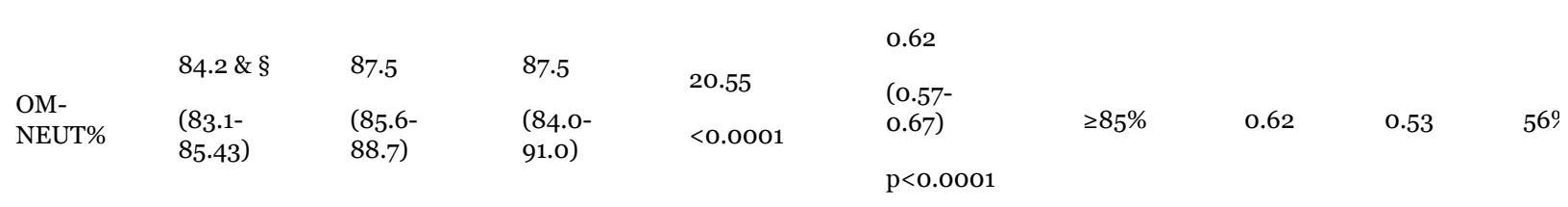

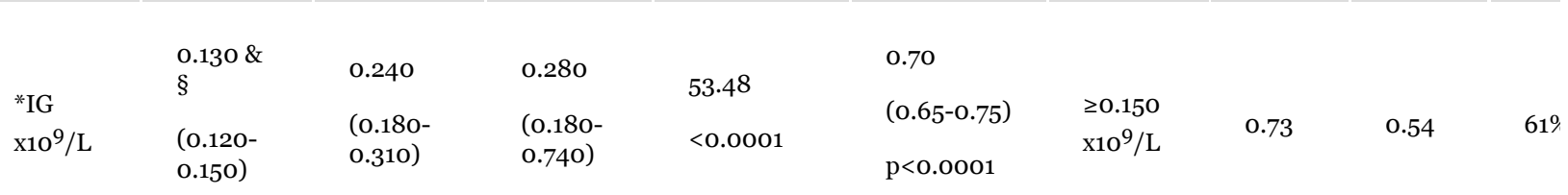

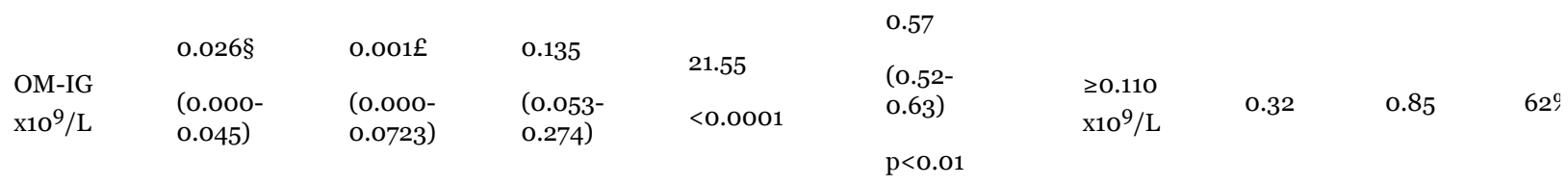




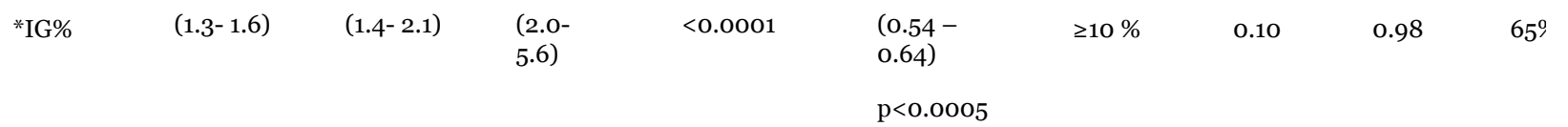

\begin{tabular}{|c|c|c|c|c|c|c|}
\hline \multirow{3}{*}{$\begin{array}{l}\text { OM-IG } \\
\%\end{array}$} & \multirow{3}{*}{$\begin{array}{l}0.5 \S \\
(0.0- \\
0.5)\end{array}$} & \multirow{3}{*}{$\begin{array}{l}0.1 £ \\
(0.0- \\
0.5)\end{array}$} & \multirow{3}{*}{$\begin{array}{l}1.1 \\
(1.0- \\
2.0)\end{array}$} & & \multirow{2}{*}{$\begin{array}{l}0.53 \\
(0.48- \\
0.58)\end{array}$} & \\
\hline & & & & 19.02 & & $/ /$ \\
\hline & & & & $<0.0001$ & & \\
\hline
\end{tabular}

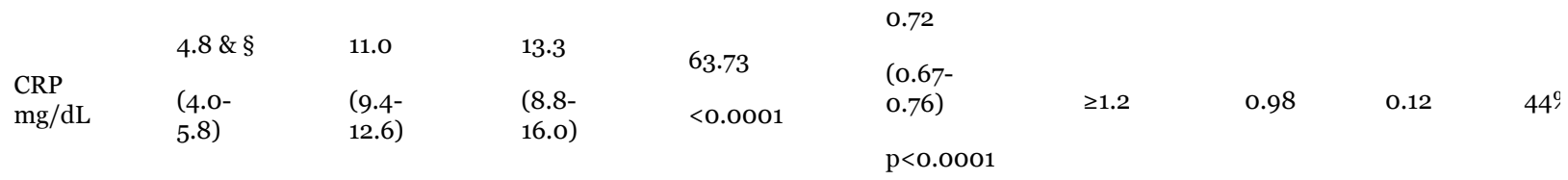

$\&$,, and $£$ statistically significant difference by Steel-Dwass-Critchlow-Fligner test for CT versus SE, CT versus SS and SE versus SS respectively.

*The data refer to all the samples examined, while in subjects 285 samples with a normal WBC count: IG\#, IG\% to cut off indicated showed a SN equal to 0.52 to 0.4 , SP equal to 0.59 to 0.98 and finally DC of $58 \%$, the $80 \%$ respectively.

\%: Values in percentage;

\#: absolute number;

AUC, Area Under the curve; CI, Confidence Interval.

Table 5. Differences between Area Under the Curve (AUC) and Receiver Operating Characteristic Curves analysis (ROC) obtained for the parameters evaluated: three of three different cell categories of leucocytes (WBC), neutrophil (NEUT) and Immature Granulocyte (IG) count using XN-90oo, of two cell category: neutrophils (OM-NEUT) and Immature Granulocyte (OM-IG) in optical microscopy (OM) and finally concentration of $\mathrm{C}$ reactive protein (CRP).

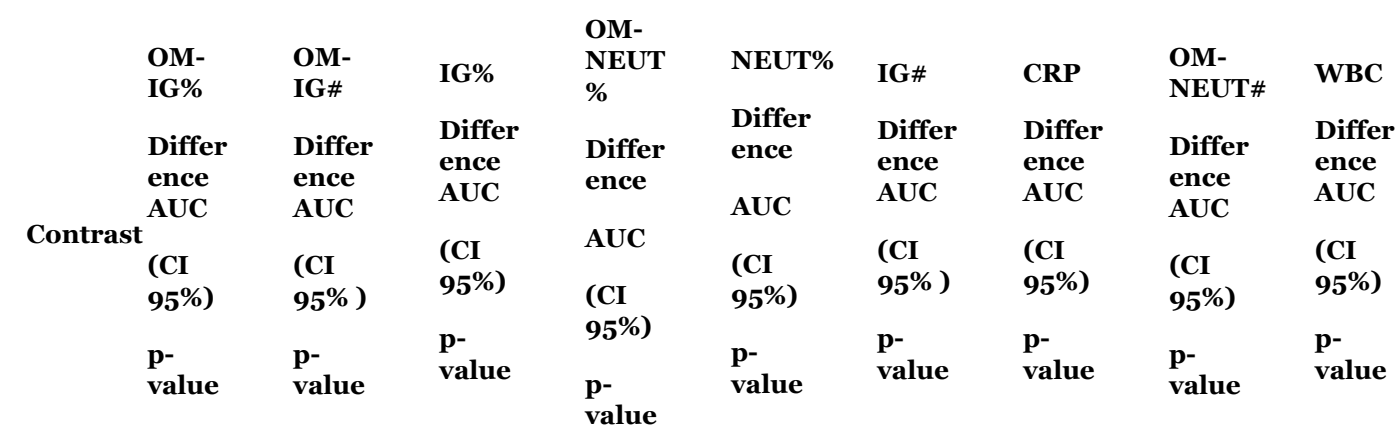

\begin{tabular}{|c|c|c|c|c|c|c|c|c|c|}
\hline \multirow{5}{*}{$\begin{array}{l}\text { NEUT\# } \\
\times 10^{9} / \mathbf{L}\end{array}$} & 0.26 & 0.22 & 0.20 & 0.17 & 0.11 & 0.10 & 0.08 & 0.01 & $0.01 \S$ \\
\hline & (o.19to & $\begin{array}{l}\text { (0.153 } \\
\text { to }\end{array}$ & (0.13 & (0.12 & (o.06 & (0.05 & (0.02 & (0.00 & $(-0.00$ \\
\hline & & $0.288)$ & $0.27)$ & $\begin{array}{l}\text { to } \\
0.22)\end{array}$ & $0.16)$ & to & to & to & to \\
\hline & $\mathrm{p}<0.00$ & & $<0.00$ & $<0.00$ & $<0.00$ & $\begin{array}{l}0.15) \\
0\end{array}$ & & & \\
\hline & 01 & 01.00 & 01 & 01 & 01 & & 0.0109 & 0.083 & 0.1845 \\
\hline
\end{tabular}

\begin{tabular}{|c|c|c|c|c|c|c|c|c|}
\hline \multirow{4}{*}{$\begin{array}{l}\text { WBC } \\
\times 10^{9} / L\end{array}$} & $\begin{array}{l}0.25 \\
\text { (o.18 }\end{array}$ & & 0.19 & 0.16 & 0.10 & 0.09 & 0.07 & $0.00 \S$ \\
\hline & $\begin{array}{l}\text { to } \\
0.32)\end{array}$ & $\begin{array}{l}0.145 \\
\text { to }\end{array}$ & $\begin{array}{l}\text { (o.12 } \\
\text { to }\end{array}$ & $\begin{array}{l}\text { (o.11 to } \\
0.22)\end{array}$ & $\begin{array}{l}\text { (o.04 } \\
\text { to }\end{array}$ & $\begin{array}{l}\text { (o.o4 } \\
\text { to }\end{array}$ & $\begin{array}{l}\text { (o.01 } \\
\text { to }\end{array}$ & $\begin{array}{l}(-0.00 \\
\text { to }\end{array}$ \\
\hline & & & o.26) & $<0.00$ & $0.16)$ & 0.14 ) & $0.13)$ & 0.01) \\
\hline & $<0.00$ & $\begin{array}{l}<0.00 \\
01\end{array}$ & 01 & 01 & 0.0008 & 0.0005 & 0.0273 & 0.4662 \\
\hline
\end{tabular}




\begin{tabular}{|c|c|c|c|c|c|c|c|}
\hline \multirow{5}{*}{$\begin{array}{l}\text { OM- } \\
\text { NEUT\# } \\
\times 10^{9} / \mathbf{L}\end{array}$} & 0.25 & 0.21 & 0.19 & 0.160 & $0.10 \S$ & 0.08 & 0.07 \\
\hline & (0.18 & (0.141 & (0.12 & (0.11 to & (0.04 & (0.03 & (0.01 \\
\hline & $0.32)$ & to & to & $0.21)$ & & & \\
\hline & & $\begin{array}{l}0.278) \\
<0.00\end{array}$ & $\begin{array}{l}0.26) \\
<000\end{array}$ & $<0.00$ & & & $0.13)$ \\
\hline & $\begin{array}{l}\mathrm{p}<0.00 \\
01\end{array}$ & 01 & 01 & 01 & 0.0003 & 0.0010 & 0.0320 \\
\hline
\end{tabular}

$\begin{array}{lllllll} & 0.18 & 0.14 & 0.12 & 0.093 & 0.03 \S & 0.02 \S \\ \text { CRP } & (0.12 & (0.079 & (0.057 & (0.03 & (-0.03 & (-0.05 \\ & \text { to } & \text { to } & \text { to } & \text { to } & \text { to } & \text { to } \\ & 0.25) & 0.207) & 0.1889 & 0.16) & 0.09) & 0.08) \\ & <0.00 & <0.00 & ) & 0.0033 & 0.3040 & 0.5813 \\ & 01 & 01 & 0.0003 & & & \end{array}$

\begin{tabular}{|c|c|c|c|c|c|}
\hline \multirow{5}{*}{$\begin{array}{l}\text { IG\# } \\
x 10^{9} / L\end{array}$} & 0.166 & 0.13 & 0.10 & 0.076 & $0.012 \S$ \\
\hline & (o.11to & $\begin{array}{l}\text { (0.07 } \\
\text { to }\end{array}$ & $\begin{array}{l}\text { (0.078 } \\
\text { to }\end{array}$ & (0.01 & $(-0.05$ \\
\hline & $0.22)$ & to & $0.131)$ & & \\
\hline & $<0.00$ & $\begin{array}{l}0.10) \\
<0.00\end{array}$ & & $0.15)$ & 0.08) \\
\hline & & 01 & $\begin{array}{l}<0.00 \\
01\end{array}$ & 0.0306 & 0.7207 \\
\hline
\end{tabular}

$\begin{array}{rllll} & 0.15 & 0.11 & 0.09 & 0.064 \\ \text { NEUT\% } & \begin{array}{lll}0.087 \\ \text { to }\end{array} & (0.05 & (0.023 & (0.03 \\ & 0.221) & \text { to } & \text { to } & \text { to } \\ & <0.00 & 0.18) & 0.163) & 0.10) \\ & 01 & 0.0008 & 0.0093 & <0.00 \\ & & & & 01\end{array}$

$\begin{array}{llll} & 0.09 & 0.049 \S & 0.03 \S \\ \text { OM- } & (0.01 & (-0.03 & (-0.05 \\ \text { NEUT } & \text { to } 0.17) & \text { to } & \text { to } \\ \text { \% } & & 0.13) & 0.10) \\ & 0.0212 & 0.1992 & 0.457\end{array}$

$\begin{array}{lll} & & 0.021 \S \\ \text { IG\% } & (0.01 & (-0.03 \\ \text { to } 0.11) & \text { to } \\ 0.0122 & 0.07) \\ & & 0.4111\end{array}$

$\begin{array}{ll} & 0.040 \\ \text { OM- } & \text { (o.03 } \\ \text { IG\# } & \text { to } \\ \mathbf{X 1 0} 9 / \mathbf{L} & 0.05) \\ & <0.00 \\ & 01\end{array}$

§: Not statistically significant difference

CI, Confidence Interval.

Figure 1. ROC curve analysis in all samples analyzed for leucocyte (WBC), neutrophil count, both absolute (NEUT\#) and percentage (NEUT\%) immature granulocyte (IG) count, both absolute (IG\#) and percentage (IG\%) obtained with XN-900o. The neutrophil count, both absolute (OM-NEUT\#) and percentage (OM- NEUT\%) and the IG count (i.e., promyelocytes, myelocytes and metamyelocytes), both absolute (OM-IG \#) and percentage (OM-IG\%). Finally, the concentration of $\mathrm{C}$ reactive protein (CRP). 


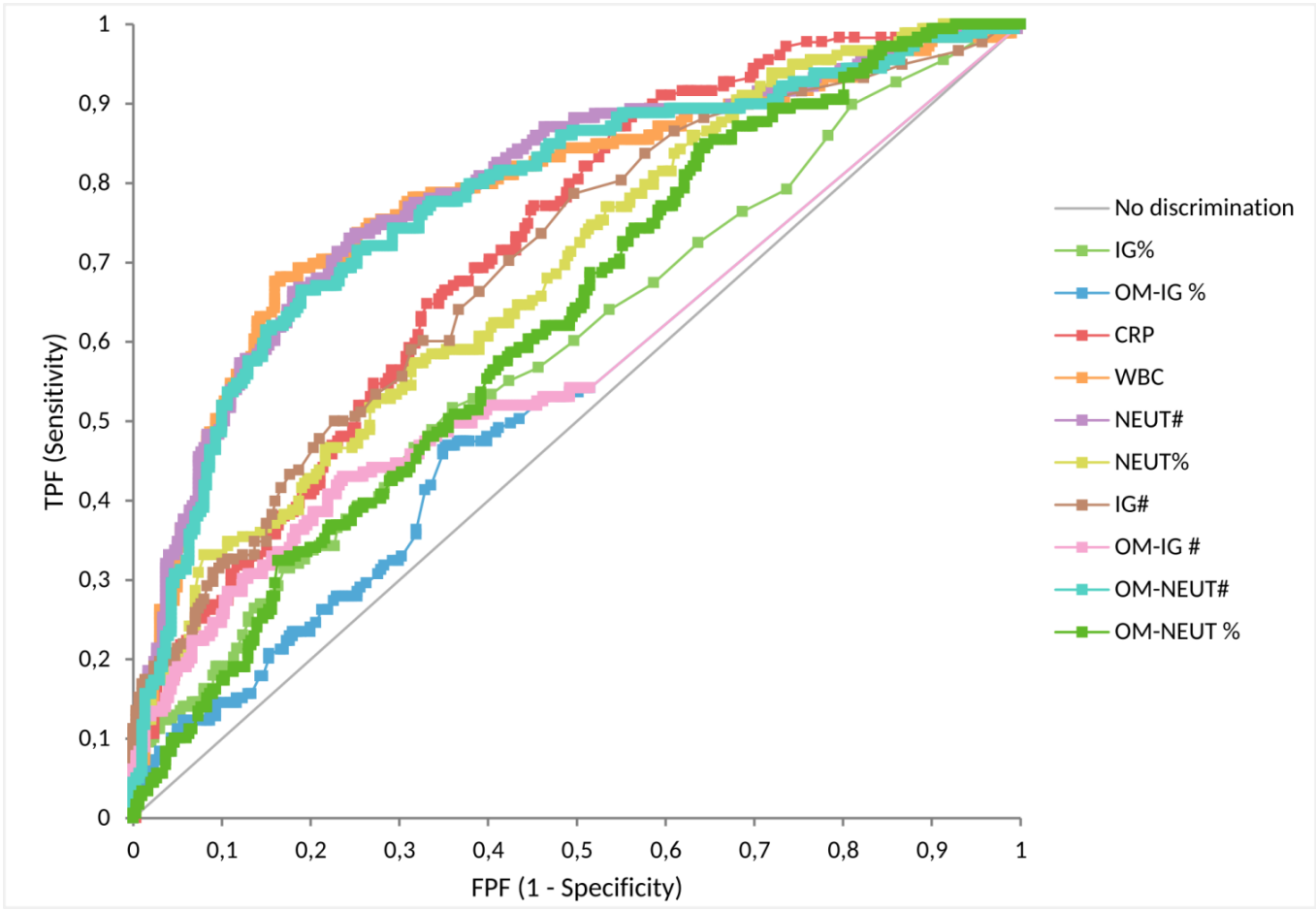

Corresponding author

Sabrina Buoro

USC Laboratorio Analisi Chimico Cliniche

A.O. Papa Giovanni XXIII

Piazza OMS, 1 -24128 Bergamo, Italy

Phone: +390352674550

$\mathrm{Fax}+390352674939$

E-mail: sbuoro@hpg23.it

Article printed from Signa Vitae: http://www.signavitae.com

URL to article: http://www.signavitae.com/2015/12/immature-granulocyte-count-on-the-new-sysmexxn-900o-performance-and-diagnosis-of-sepsis-in-the-intensive-care-unit/

Copyright (C) 2015 Signa Vitae. All rights reserved. 